\title{
APLIKASI KAMUS BAHASA JAWA INDONESIA DENGAN ALGORITMA RAITA BERBASIS ANDROID
}

\author{
Khairul ${ }^{1}$ \\ Sri haryati ${ }^{2}$ \\ Yanti Yusman ${ }^{3}$
}

\begin{abstract}
Language is a means to communicate. In this world there are many languages, including Indonesian and Javanese. Knowledge of language is very important because in a speaking or conversation requires a language. The means to learn the language is by using a dictionary. There are many types of dictionaries ranging from dictionaries in the form of books to form mobile phone applications, but if you want to learn the language can use the application of Java-based Indonesian android dictionary that provides services to translate the vocabulary. The purpose of making a dictionary application is to help users in facilitating the search for vocabulary in the Java language and Indonesia. Based on the test results, application Dictionary Java Indonesia with Raita Method Based Android is just to find the vocabulary only, the application loads menu added data and edit data to add and change data if there is an error. Applications Dictionary Java Indonesia Based Android can be run on smarthphone android system.
\end{abstract}

Keywords: Language, Dictionary, Application, Android, Raita Algorthm.

\section{INTISARI}

Bahasa merupakan sarana untuk berkomunikasi. Di dunia ini banyak sekali bahasa, antara lain bahasa Indonesia dan Jawa. Pengetahuan tentang bahasa sangatlah penting karena dalam sebuah percakapan atau pembicaraan memerlukan sebuah bahasa. Sarana untuk mempelajari bahasa yaitu dengan menggunakan kamus. Ada banyak sekali jenis kamus mulai dari kamus berbentuk buku sampai berbentuk aplikasi mobile phone, akan tetapi jika ingin mempelajari bahasa dapat memakai aplikasi kamus Jawa Indonesia berbasis android yang menyediakan layanan untuk menterjemahkan kosakata. Tujuan pembuatan aplikasi kamus yaitu guna membantu pengguna dalam mempermudah pencarian kosakata dalam bahasa Jawa dan Indonesia.Berdasarkan hasil uji, aplikasi Kamus Jawa Indonesia dengan Metode Raita Berbasis Android ini hanya untuk mencari kosakata saja, aplikasi memuat menu tambah data dan edit data untuk menambah dan mengedit data apabila ada kesalahan. Aplikasi Kamus Jawa Indonesia Berbasis Android ini dapat dijalankan pada smartphone bersistem android.

Kata kunci : Bahasa, Kamus, Aplikasi, Android, Algoritma Raita.

\footnotetext{
${ }^{1}$ Dosen Prodi Sistem Komputer Universitas Pembangunan Panca Budi Medan

2. Dosen Prodi Sistem Komputer Universitas Pembangunan Panca Budi Medan

${ }^{3 .}$ Dosen Prodi Sistem Komputer Universitas Pembangunan Panca Budi Medan
} 


\section{PENDAHULUAN}

Bahasa jawa adalah bahasa
yang digunakan penduduk suku
bangsa Jawa di
Tengah,Yogyakarta \& Jawa Timur.
Selain itu, Bahasa Jawa juga
digunakan oleh penduduk yang
tinggal beberapa daerah lain seperti
di Banten terutama kota Serang,
kabupaten Serang, kota Cilegon dan
kabupaten Tangerang, Jawa Barat
khususnya kawasan Pantai utara
terbentang dari pesisir utara Karawang, Subang, Indramayu, kota Cirebon dan kabupaten Cirebon. Namun masyarakat di luar pulau jawa juga banyak menggunakan bahasa jawa sebagai akibat dari efek transmigrasi penduduk bangsa jawa ke wilayah indonesia lainnya. Seiring berjalannya waktu penggunaan bahasa jawa dalam kehidupan sehari khususnya suku jawa sendiri semakin luntur akibat pengaruh globalisasi bahasa asing dan kurangnya perhatian orang tua dalam membudayakan anak keturunannya untuk berkomunikasi dalam bahasa jawa dalam lingkungan keluarga. Sehingga generasi sekarang tidak mampu menguasai bahasa leluhurnya yaitu suku bangsa jawa. Apalagi suku jawa adalah suku mayoritas bangsa indonesia. Sehingga diperlukan adanya sebuah upaya dalam melestarikan kebudayaan bangsa indonesia salah satunya adalah bahasa jawa dengan membuat kamus digital.

Kamus digital adalah kamus yang bentuknya berupa software atau aplikasi. 'E-Kamus' bisa berbentuk software yang perlu diinstal dikomputer (berbasis komputer), atau diletakkan di laman (halaman) website, atau berupa aplikasi yang kini dapat dioperasikan melalui perangkat mobile seperti ponsel, tablet, dan sebagainya.
Android sebagai salah satu sistem operasi untuk telepon seluler yang berbasis Linux menyediakan platform terbuka bagi para pengembang untuk menciptakan aplikasi mereka sendiri untuk digunakan oleh bermacam peranti bergerak. Meningkatnya pertumbuhan Android selain karena banyaknya orang yang menyukai Android karena sistem keterbukaannya alias Open Source, banyak aplikasi bersifat free alias gratis, juga didukung fitur serta aplikasi pendukungnya lebih banyak. Sehingga memunculkan ide untuk membangun sebuah aplikasi kamus bahasa jawa indonesia berbasis android.

Untuk mempercepat proses pencarian kosokata dalam aplikasi kamus bahasa jawa indonesia berbasis android maka diperlukan sebuah algoritma yang bertujuan untuk efesiensi dan efektifitas penggunaan kamus. Salah satu algoritma yang umum digunakan dalam proses searching adalah Algoritma Raita. Algoritma RAITA merupakan salah satu metode model pencarian dengan mencocokan pola kata dari sebuah string dengan pola kata yang ingin dicari, proses pencocokan pola tersebut dilakukan dengan membandingkan karakter. Sehingga diharapkan dapat membuat proses pencarian kosa kata dalam aplikasi kamus bahasa jawa indonesia dapat berjalan optimal.

\section{PENDEKATAN MASALAH Aplikasi}

Aplikasi perangkat lunak (software application) adalah suatu subkelas perangkat lunak komputer yang memanfaatkan kemampuan komputer langsung untuk melakukan suatu tugas yang diinginkan pengguna (Neti, 2012)[1]. Biasanya 
dibandingkan dengan perangkat lunak sistem yang mengintegrasikan berbagai kemampuan komputer, tetapi tidak secara langsung menerapkan kemampuan tersebut untuk mengerjakan suatu tugas yang menguntungkan pengguna. Contoh utama perangkat lunak aplikasi adalah pengolah kata, lembar kerja, dan pemutar media.

\section{Kamus}

Kamus adalah sejenis buku rujukan yang menerangkan makna kata-kata. Kamus juga berfungsi untuk membantu seseorang mengenal perkataan baru. Selain menerangkan maksud kata, kamus juga mungkin mempunyai pedoman sebutan, asal-usul (etimologi) sesuatu perkataan dan juga contoh penggunaan bagi sesuatu perkataan. Untuk memperjelas kadang kala terdapat juga ilustrasi di dalam kamus.

\section{Sejarah Bahasa Jawa}

Sejarah Sastra Jawa dimulai dengan sebuah prasasti yang ditemukan di daerah Sukabumi (Sukobumi), Pare, Kediri Jawa Timur. Prasasti yang biasa disebut dengan nama Prasasti Sukabumi ini bertarikh 25 Maret tahun 804 Masehi. Isinya ditulis dalam bahasa Jawa Kuna. Bahasa Jawa (basa Jawa aksara Jawa) adalah bahasa yang digunakan penduduk suku bangsa Jawa di Jawa Tengah,Yogyakarta \& Jawa Timur. Selain itu, Bahasa Jawa juga digunakan oleh penduduk yang tinggal beberapa daerah lain seperti di Banten terutama kota Serang, kabupaten Serang, kota Cilegon dan kabupaten Tangerang, Jawa Barat khususnya kawasan Pantai utara terbentang dari pesisir utara Karawang, Subang, Indramayu, kota Cirebon dan kabupaten Cirebon.

\section{Android}

Android adalah sebuah sistem operasi untuk perangkat mobile berbasis linux yang mencakup sistem operasi, middleware, dan aplikasi. Android menyediakan platform terbuka bagi para pengembang untuk membuat aplikasi mereka sendiri. Pada awalnya dikembangkan oleh Android Inc, sebuah perusahaan pendatang baru yang membuat perangkat lunak untuk ponsel yang kemudian dibeli oleh Google Inc. Untuk pengembangannya, dibentuklah Open Handset Alliance (OHA), konsorsium dari 34 perusahaan perangkat keras, perangkat lunak, dan telekomunikasi termasuk Google, HTC, Intel, Motorola, Qualcomm, T-Mobile, dan Nvidia (M. Ichwan, 2013) [2].

\section{Algoritma}

Pengertian algoritma adalah suatu urutan dari beberapa langkah yang logis guna menyelesaikan masalah (Patel\&Thakkar, 2013)[3]. Algoritma sangat diperlukan untuk mengolah data yang ada di komputer. Dalam sistem komputer, pengertian algoritma ialah logika yang dibuat dengan memakai software oleh para pembuat perangkat lunak untuk membuat software tersebut menjadi lebih bagus. Algoritma berbeda dengan Logaritma. Perlu diketahui juga bahwa logaritma adalah sebuah operasi di ilmu matematika guna menghitung kebalikan eksponen dari sebuah perpangkatan.

\section{Algoritma RAITA}

Algoritma Raita merupakan bagian dari algoritma exact string matching yaitu pencocokan string secara tepat dengan susunan karakter dalam string yang dicocokkan memiliki jumlah maupun urutan karakter dalam string yang sama. Raita merancang sebuah algoritma dengan membandingkan karakter yang terakhir dari pola yang diawali dari karakter paling kanan 
dari "jendela". Jika cocok, kemudian karakter pertama dari pola teks paling kiri dari jendela juga dibandingkan. Jika cocok, maka akan dibandingkan karakter tengah pola dengan karakter teks tengah jendela. Pada akhirnya, jika benar-benar cocok, maka algoritma membandingkan karakter lain mulai dari pola karakter kedua ke karakter kedua terakhir, dan akan membandingkan dengan karakter tengah lagi (Bhandari \& Kumar, 2014) [4].

\section{HASIL DAN PEMBAHASAN}

Proses pencarian dengan
menggunakan algoritma RAITA
memiliki langkah-langkah prose sebagai berikut:

1. Buat tabel pergeseran pola yang dicari $(P)$ sebagai kata yang akan dicari pada teks.

2. Jika dalam proses pembandingan terjadi ketidakcocokan antara pasangan karakter pada akhir pola dengan karakter teks, pergeseran dilakukan sesuai nilai karakter teks pada tabel BmBc.

3. Jika dalam proses pembandingan akhir pola terjadi ketidakcocokan lagi maka karakter akan digeser lagi sesuai tabel $\mathrm{BmBc}$

4. Jika karakter akhir pola dengan karakter pada teks yang sedang dibandingkan cocok, maka posisi karakter pada pola dan teks akan memiliki nilai nol (0), dan dilanjutkan pencocokan pada karakter awal pola. Jika cocok maka dilanjutkan pencocokan dengan karakter tengah pola.

5. Jika akhir, awal dan tengah pola telah cocok. Pencocokan dilanjutkan dengan bagian kanan dari awal karakter pada pola, jika cocok maka dicocokkan pada bagian kanan tengah pola.

\begin{abstract}
Implementasi sistem yang dirancang menggunakan Sistem Operasi Windows 7, Android Studio, MySQL Service. berikut adalah tampilan program aplikasi ketika dijalankan
\end{abstract}

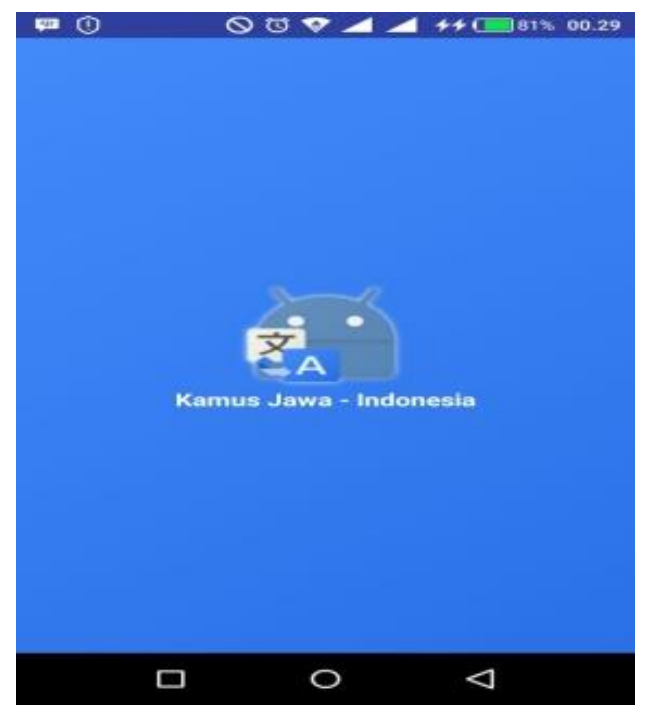

Gambar 1. Halaman Splash Screen

Gambar 1 merupakan halaman splash screen yang tampil ketika program pertama sekali dijalankan, splash screen ini akan hilang dalam waktu beberapa detik dan masuk kedalam halaman kamus seperti berikut:

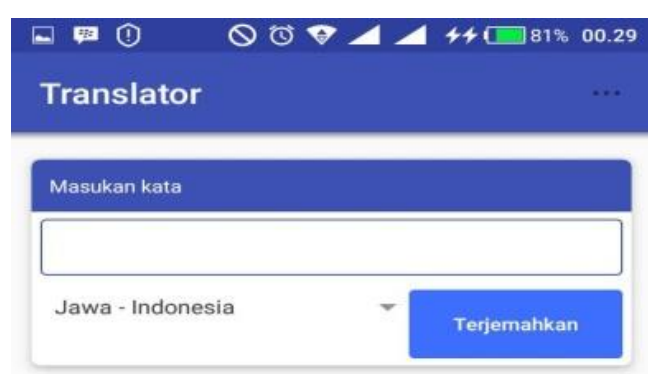

\section{Gambar 2. Halaman kamus}

Halaman kamus digunakan oleh pengguna untuk mencari arti kata dalam bahasa jawa atapun sebaliknya, untuk pengujian proses 
pencarian kamus dapat dilihat pada gambar berikut:

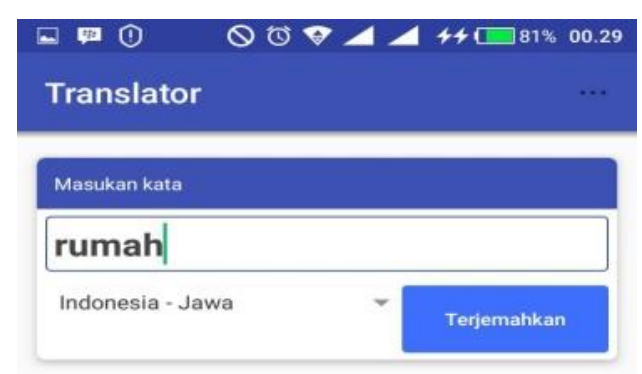

Gambar 3. Arti Bahasa Indonesia - Jawa

Sebagai contoh pengujian penulis memasukkan kata dalam bahasa Indonesia "Rumah" untuk dicari arti kata dalam bahasa jawa yang sudah terdapat didalam database, untuk melakukanan proses translasi ditekan tombol terjemahkan dan hasilnya sebagai berikut:

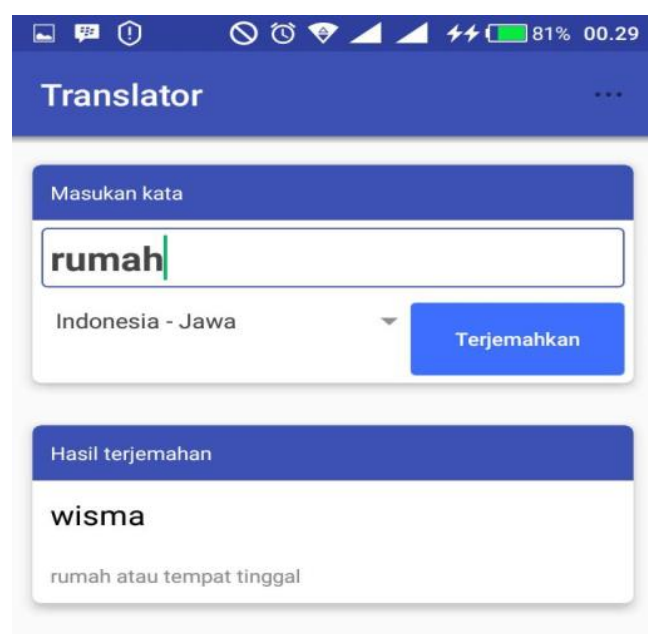

Gambar 4. Hasil terjemahan rumah

Gambar 5 menampilkan kata dalam bahasa jawa yang memiliki arti rumah dan juga menampilkan keterangan dari kata bahasa jawa tersebut, pengujian lainnya dapat dilihat pada gambar berikut:

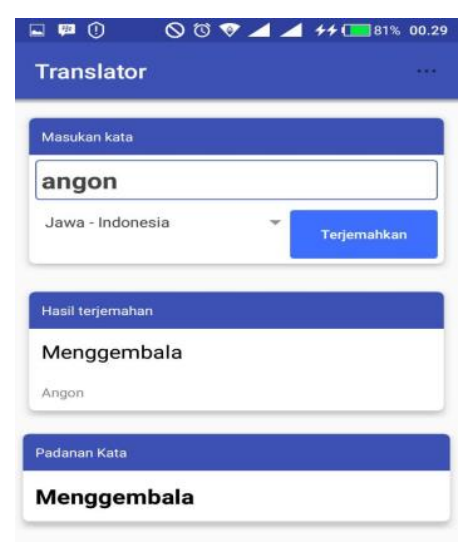

Gambar 5 Hasil terjemahan kata jawa indonesia

Setelah menterjemahkan kata dari bahasa jawa dan bahasa Indonesia, pengujian berikutnya adalah menguji proses login oleh administrator untuk menambah data di kamus, berikut adalah halaman loginnya.

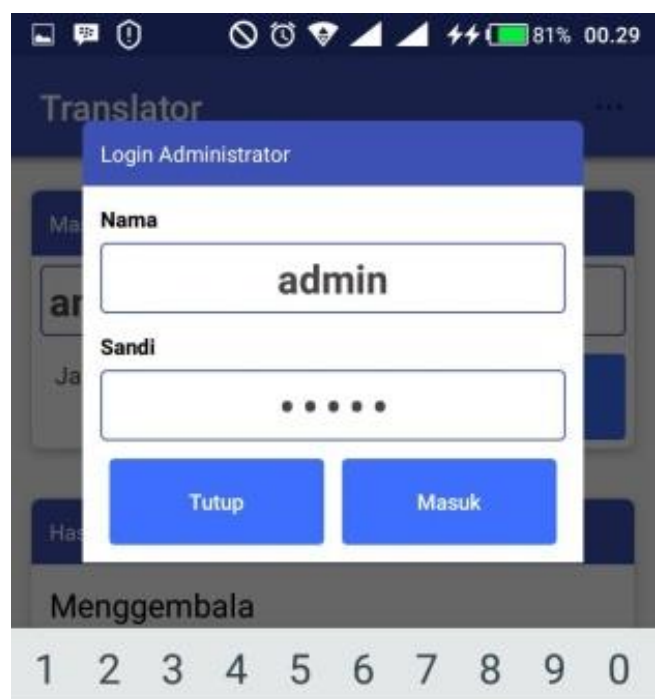

\section{Gambar 6. Halaman login}

Halaman login digunakan bagi administrator untuk masuk kedalam sistem admin, untuk login harus memasukkan nama dan sandi, pada pengujian ini nama=admin, sandi=admin dan dilanjutkan dengan menekan tombol masuk, ketika sukses maka akan masuk kedalam halaman admin berikut: 


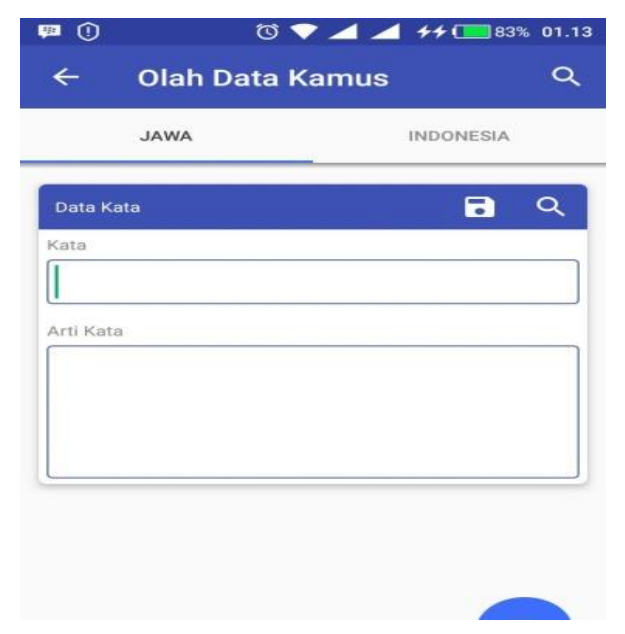

Gambar 7. Halaman admin olah data kamus

\begin{abstract}
Gambar 7 merupakan halaman olah data kamus yang digunakan oleh admin untuk menambah, mengubah dan menghapus data yang ada didalam sistem, untuk lebih detail pengujian ini bisa di uji langsung pada smartphone.
\end{abstract}

\section{KESIMPULAN}

Berdasarkan keterangan di atas penulis dapat menarik kesimpulan sebagai berikut ;
1. Sistem pencarian yang dirancang dengan menggunakan algoritma RAITA yang dirancang mampu menampilkan kata yang ada didalam database lebih cepat dan padanan.

2. Proses pencarian yang dilakukan dengan algoritma RAITA secara implisit sistem dimana kata yang akan dicari akan diproses berdasarkan array yang sesuai dengan string masukan pengguna.

3. Perancangan sistem dengan Android Studio sebagai toll bahasa pemrograman android dalam membuat aplikasi sudah tepat dikarenakan kemudahan dalam proses pengembangan aplikasi.
Berdasarkan kesimpulan diatas, penulis mengharapkan adanya :

1. Proses pencarian kedepannya bisa dikombinasikan dengan algoritma Boyer Moore atau String Matching sehingga proses pencarian lebih akurat lagi.

2. Proses pencarian konten kedepannya bisa ditambahkan dengan melakukan pencarian pada secara online dengan melakukan parsing dari kamus online.

3. Dukungan database diperlukan sehingga proses pencarian yang sudah pernah dilakukan akan lebih cepat dikarenakan tidak memproses sebanyak 2 kali untuk konten yang sama.

\section{DAFTAR PUSTAKA}

[1] Neti. 2012. Perancangan Aplikasi Rental Mobil Pada CV Karya Bersama Palembang.

[2] Muhammad Ichwan, Milda Gustiana Husada, M. lqbal Ar Rasyid. 2013. Pembangunan Prototipe Sistem Pengendalian Peralatan Listrik Pada Platform Android. Jurnal Informatika. No. 1, Vol. 4, Januari - April 2013 : 2087-5266

[3] Patel, Urmila dan Mr. Mitesh Thakkar. 2013. Survey on Exact Pattern Matching Algorithm. International Journal for Scientific Research \& Development Vol. 1, Issue 8, 2013 : 2321-0613

[4] Bhandari, Jamuna dan Anil Kumar. 2014. String Matching Rules Used By Variants of Boyer-Moore Algorithm. Journal of Global Research in Computer Science. Volume 5, No. 1, Januari 2014 : 2229$371 \mathrm{X}$. 